\title{
The Role of Rhizobacterial Inoculum and Formulated Soil Amendment in Improving Soil Chemical-Biological Properties, Chlorophyll Content and Agronomic Efficiency of Maize under Marginal Soils
}

\author{
Betty Natalie Fitriatin ${ }^{1, *}$, Debora Dellaocto Melati Ambarita ${ }^{2}$, Mieke Rochimi \\ Setiawati ${ }^{1}$ and Tualar Simarmata ${ }^{1}$ \\ ${ }^{1}$ Department of Soil Sciences and Land Resouces, Agriculture Faculty, Universitas Padjadjaran. Jatinangor 45363-West Java - Indonesia; \\ ${ }^{2}$ Postgraduate of Soil Science, Agriculture Faculty, Universitas Padjadjaran. Jatinangor 45363-West Java - Indonesia
}

Received: February 27, 2021; Revised: May 17, 2021; Accepted: July 19, 2021

\begin{abstract}
Intensively use of chemical fertilizers accelerates organic matter and soil health degradation. Consequently, the soil capacity in providing the essential nutrient is decreasing significantly. The research was conducted to investigate the contribution of selected rhizobacteria inoculant as biofertilizers and formulated soil amendment (FSA) for enhancing the soil organic carbon, abundance of nitrogen fixer bacteria (NFB), phosphate solubilizing bacteria (PSB), chlorophyll content and yield of maize in marginal soils. The experiment was arranged as Randomized Complete Blocks Design (RCBD) consisting of two factors and provide with three replications. The first factor were biofertilizers (consortia of PSB and N-fixing bacteria combined with formulated soil amendment (compost 50\%, biochar 20\%, humid acid $1 \%$, guano $9 \%$ ) and the second factor were the rate of N,P fertilizers $100 \%, 80 \%, 60 \%, 40 \%$ recommended doses $\left(138 ; 110.4 ; 82.8 ; 55.2 \mathrm{~kg} \mathrm{ha}^{-1} \mathrm{~N}\right.$ and 36; 28.8; 21.6; $14.4 \mathrm{~kg} \mathrm{ha}^{-1} \mathrm{P}$ ). The results revealed that application of biofertilizers and FSA increased soil C-org, population of PSB and $\mathrm{N}$-fixing bacteria, chlorophyll leaves and yield of maize were increased significantly. The highest population of PSB and $\mathrm{N}$-fixing bacteria, chlorophyll leaves and yield of maize were obtained by application of $1.200 \mathrm{~g}$ ha- ${ }^{1}$ of biofertilizers and $2 \mathrm{t}$ $\mathrm{ha}^{-1}$ of organic FSA. The application of biofertilizers and FSA with $60-100 \%$ NP fertilizer could increase maize yields. Additionally, fertilizers efficiency was increased by $40 \%$. This finding recommends the use of $1200 \mathrm{~g}$ of biofertilizers inoculant and $2 \mathrm{t}$ of FSA to improved the soil properties and increased the maize productivity on marginal soils.
\end{abstract}

Keywords: N-fixer, organic carbon, P-solubilizer, fertilizers efficiency

\section{Introduction}

Concern for environmental pollution due to the use of various chemicals especially inorganic fertilizers and synthetic pesticides as well as health and environmental reasons makes sustainable agriculture one of the alternatives of modern agriculture. One effective step that can be developed in sustainable agriculture is the use of microbes that are useful in facilitating or increasing the availability of soil nutrients or known as biofertilizers (Macik et al., 2020). Microbes which are commonly used as an active ingredient in biological fertilizers are nitrogenfixing bacteria, phosphate solubilizing microbes, mycorrhizae, and phytohormone-producing bacteria (Wahane et al., 2020).

Beneficial microbe that has a role to facilitate available phosphate is phosphate-solubilizing microbes (PSM). These microbes are able to improve plant growth and increase soil P availability (Jayakumara et al., 2019; Wu et al., 2019) and produce phosphatase enzyme (Chen and
Liu, 2019) and produce phytohormone (Fitriatin et al., 2020).

Some bacteria can convert atmospheric nitrogen into ammonia in symbiosis with plants or without symbiosis. Gentili and Jumpponen (2006) reported that Azotobacter sp. and Azospirillum sp. are non-symbiotic and free-living bacteria that play a role in $\mathrm{N}$ fixation. Steenhoudt and Vanderleyden (2000) stated that Azospirillum is the best genus from Plant Growth-Promoting Rhizobacteria (PGPR) genera group because its interactions with several plant roots are able to fix nitrogen and produce plant growth hormones.

Biofertilizers play an important role to sustainably increase land productivity and influence plant growth and yield positively (Itelima et al. 2018). Fitriatin et al. (2019) reported that the application of biofertilizers that contain consortium of phosphate-solubilizing microbes and nitrogen-fixing bacteria increase soil nitrogen and $\mathrm{P}$ availability. The application of biofertilizers and organic ameliorants is a step to reduce soil damage due to excessive use of inorganic fertilizers. The use of organic fertilizers is expected to supplement the use of chemical

\footnotetext{
* Corresponding author e-mail: betty.natalie@unpad.ac.id.
} 
fertilizers. More research is needed to know more about the impact of biofertilizers which contain phosphatesolubilizing microbes and nitrogen-fixing bacteria with formulated soil amendment in increasing soil carbon, population of PSM, chlorophyll content and yield of maize.

\section{Materials and Method}

The field experiment was conducted at Horticultural Seed Development Centre and Various Plants Pasir Banteng, Sumedang, West Java on Inceptisols. A composite sample was taken from the field from depth 0 $30 \mathrm{~cm}$ for physical and chemical analysis of the soil. The physic-chemical properties of the soil are as follows: texture dusty clay; $\mathrm{pH} 5.95 ; \mathrm{C}_{\text {org }} 2.3 \%$; $\mathrm{N}_{\text {total }} 0.21 \%$; $\mathrm{C} / \mathrm{N}$ 10; $\mathrm{P}_{2} \mathrm{O}_{5} \mathrm{HCl} 25 \% 60.75 \mathrm{mg} 100 \mathrm{~g}^{-1} ; \mathrm{P}_{2} \mathrm{O}_{5}$ (Bray) 11.36 ppm; and CEC 23.61 cmol. $\mathrm{kg}^{-1}$.

The experiment was laid out in Randomized Complete Blocks Design (RCBD) consisting of two factors and three replications (The plot size was $3 \mathrm{~m} \times 1.5 \mathrm{~m}$ with inter row spacing of $75 \mathrm{~cm}$ and intra row spacing of $25 \mathrm{~cm}$ ). The first factors were biofertilizers and formulated soil amendment (FSA) (control; biofertilizers; FSA ; and biofertilizers + FSA). Biofertilizers with a peat base material carrier contain $\mathrm{N}$-fixer bacteria (Azotobacter chroococcum, and Azospirillum sp.) and phosphate solubilizing bacteria (Bulkholderia vietnamiensi and Enterobacter ludwigii). These bacteria were selected in isolation from several ecosystems including rice rhizosphere, peanut rhizosphere and sweet potato rhizosphere. Azotobacter and Azospirillum were cultured on JNFb media while Enterobacter and Bulkholderia were cultured on Pikovskaya media. Formulated soil amendment contains mixture of compost $50 \%$, biochar $20 \%$, humid acid $1 \%$, and guano $9 \%$. The second factor was the rate of NP fertilizers $100 \%, 80 \%, 60 \%, 40 \%$ recommended doses (138; 110.4; 82.8; $55.2 \mathrm{~kg} \mathrm{ha}^{-1} \mathrm{~N}$ and 36; 28.8; 21.6; $\left.14.4 \mathrm{~kg} \mathrm{ha}^{-1} \mathrm{P}\right)$ with Urea $(46 \% \mathrm{~N})$ and single super phosphate $(36 \% \mathrm{P})$ which is applied around the planting hole. Maize seeds used BISI 2 with a germination rate of more than $85 \%$.

\subsection{Data collection}

\section{Soil Organic Carbon (SOC)}

Was determined by oxidimetric titration Walkley and Black method (Nelson and Sommers 1982).

\section{The number of bacterial population}

Nitrogen fixing bacteria and phosphate solubilizing bacteria population were determined by serial dilution plate count technique (Zhang et al. 2012).

\section{Content of chlorophyll}

Chlorophyll content of leaf was measured by using Soil Plant Analysis Development (SPAD) meter (SPAD 502, Minolta, Japan). Five plants were randomly selected from each plot to measure chlorophyll content.

\section{Grain yield}

To calculate grain yield by using given formula:
$\mathrm{Gr}(\mathrm{Kg}$ ha -1$)=\frac{\text { yield plot at } 14 \% \text { moisture }(\mathrm{Kg})}{\text { plot size in m2 }} \times 10000 \mathrm{~m} 2$

\section{Agronomic efficiency}

Agronomic efficiency was calculated by equation below (Zemichael et al. 2017):

$$
A E(k g k g-1)=\frac{G f-G u}{N a}
$$

If: Gf: the grain yield in the fertilized plot (Kg).

$\mathrm{Gu}$ : the grain yield in the un fertilized plot (Kg).

$\mathrm{Na}$ : the quantity of nutrient applied (Kg).

Data were processed using DSAASTAT (Dipartimento in the Scienze Agrarie ed Ambientali Statistic) and Duncan's multiple range test with a 95\% confidence level to determine differences in mean values between treatments.

\section{Results}

\subsection{Soil Organic Carbon}

The soil organic $\mathrm{C}$ content of the soil was measured at the end of the vegetative phase. The experimental results show that there was no interaction between biofertilizers and FSA with NP fertilizers (Table 1).

Table 1. Soil organic carbon as affected by biofertilizers, FSA and $\mathrm{N}$, P fertilizers

\begin{tabular}{ll}
\hline Treatments & Soil Organic C (\%) \\
\hline $\begin{array}{l}\text { Biofertilizers and formulated soil } \\
\text { amendment (FSA) }\end{array}$ \\
- Control & $3.80 \mathrm{a}$ \\
- Biofertilizers & $3.83 \mathrm{a}$ \\
- FSA & $4.12 \mathrm{~b}$ \\
- Biofertilizers + FSA & $4.31 \mathrm{~b}$ \\
\hline N, P Fertilizers & \\
$100 \%$ & $4.01 \mathrm{a}$ \\
- $\quad 80 \%$ & $4.02 \mathrm{a}$ \\
- $\quad 60 \%$ & $4.19 \mathrm{a}$ \\
- $\quad 40 \%$ & $3.84 \mathrm{a}$ \\
\hline Note: Numbers followed by the same letter are not significantly \\
different according to Duncan's test at 5\% significance level
\end{tabular}

Biofertilizers did not significantly increase soil organic carbon. Different results are shown by the treatment of FSA which was able to increase soil organic carbon significantly. The combination treatment of biofertilizers and FSA increased soil organic carbon up to $13.4 \%$ compared to control.

\subsection{Chlorophyll content}

The statistical analysis showed the interaction between biofertilizers and FSA with NP fertilizer on chlorophyll content of maize leaves (Table 2). In general, the application of biofertilizers and FSA at various doses of NP fertilizers increased the chlorophyll content. The combination of biofertilizers and FSA at various doses of NP fertilizers higher chlorophyll content compared to the treatment of only biofertilizers or FSA. Chlorophyll content tends to be higher in the treatment of high NP fertilizer doses. The treatment of $100 \%$ NP fertilizers and 
the combination of biofertilizers and FSA gives the highest C soil content (39.47).

Table 2. Chlorophyll content of maize leaves (SPAD)

\begin{tabular}{lcccc}
\hline \multirow{2}{*}{ Treatments } & \multicolumn{4}{c}{ N, P Fertilizers } \\
\cline { 2 - 5 } & $100 \%$ & $80 \%$ & $60 \%$ & $40 \%$ \\
\hline \multirow{2}{*}{ control } & $32.83 \mathrm{a}$ & $31.87 \mathrm{a}$ & $30.73 \mathrm{~b}$ & $28.90 \mathrm{a}$ \\
& (d) & (c) & (b) & (a) \\
Biofertilizers & $38.90 \mathrm{c}$ & $31.80 \mathrm{a}$ & $29.47 \mathrm{a}$ & $29.77 \mathrm{ab}$ \\
& (c) & (b) & (a) & (a) \\
FSA & $35.07 \mathrm{~b}$ & $31.73 \mathrm{a}$ & $30.30 \mathrm{ab}$ & $29.50 \mathrm{ab}$ \\
& (c) & (b) & (a) & (a) \\
Biofertilizers + FSA & $39.47 \mathrm{c}$ & $34.37 \mathrm{~b}$ & $32.20 \mathrm{c}$ & $30.20 \mathrm{~b}$ \\
& (d) & (c) & (b) & (a) \\
\hline
\end{tabular}

Note: Numbers followed by the same letter are not significantly different according to Duncan's test at 5\% significance level. Letters in parentheses are read horizontally. Letters without brackets are read vertically

\subsection{Soil microbe population}

Beneficial soil microbe populations measured were PSB and N-fixer bacteria at the end of vegetative period. The PSB population ranges between 2.7-57.55 x $10^{7}$ colony forming unit (CFU) $\mathrm{g}^{-1}$ (Table 3).

The results of statistical analysis show a significant interaction between biofertilizers and FSA with NP fertilizer on PSB population. Biofertilizers and FSA increased population of PSB at various doses of NP fertilizers. Application of $80-100 \%$ NP fertilizers and the combination of biofertilizers and FSA provide a better influence on the PSB population (55.9-57.55 x 10 $\mathrm{CFU} g$ $\left.{ }^{1}\right)$.

Table 3. Population of phosphate solubilizing bacteria $\left(10^{7} \mathrm{CFU}\right.$ $\left.\mathrm{g}^{-1}\right)$

\begin{tabular}{lllll}
\hline \multirow{5}{*}{ Treatments } & \multicolumn{4}{l}{ N,P Fertilizer s } \\
\cline { 2 - 5 } & $100 \%$ & $80 \%$ & $60 \%$ & $40 \%$ \\
\hline Control & 20.67 a & 22.00 a & 21.67 a & 20.67 a \\
& (a) & (a) & (a) & (a) \\
Biofertilizers & 52.25 b & 51.10 c & 48.50 c & 48.81 c \\
& (c) & (bc) & (a) & (ab) \\
FSA & 27.35 c & 26.33 b & 24.73 b & 23.63 b \\
& (b) & (b) & (ab) & (a) \\
Biofertilizers + FSA & 57.55 d & 55.90 d & 50.43 c & 47.18 c
\end{tabular}

$\begin{array}{llll}\text { (c) } & \text { (c) } & \text { (b) } & \text { (a) }\end{array}$

The population of $\mathrm{N}$-fixing bacteria was affected by the application of biofertilizers and FSA at several doses of N and $\mathrm{P}$ fertilizers. The statistical analysis shows a significant interaction between biofertilizers and FSA with NP fertilizer on N-fixing bacteria population.

Application of $80-100 \%$ NP fertilizers and the combination of biofertilizers and FSA provided a better influence on the population of (N-fixing bacteria (47.37 x $10^{7} \mathrm{CFU} \mathrm{g}^{-1}$ ). Fertilizing low-dose NP tended to give a lower population number of $\mathrm{N}$ fixing bacteria compared to other treatments (Table 4).
Table 4. Population of N-fixing bacteria $\left(10^{6} \mathrm{CFU} \mathrm{g}^{-1}\right)$

\begin{tabular}{lllll}
\hline \multirow{2}{*}{ Treatments } & \multicolumn{5}{l}{ N,P Fertilizer s } \\
\cline { 2 - 5 } & $100 \%$ & $80 \%$ & $60 \%$ & $40 \%$ \\
\hline control & 12.45 a & 12.17 a & 10.83 a & 11.933 a \\
& (a) & (a) & (a) & (a) \\
Biofertilizers & 25.18 b & 26.37 b & 22.933 c & 23.77 b \\
& (a) & (a) & (a) & (a) \\
FSA & 16.92 a & 16.9 a & 15.78 b & 19.78 b \\
& (a) & (a) & (a) & (a) \\
Biofertilizers + FSA & 47.37 c & 33.63 c & 28.17 c & 22.38 b \\
& (d) & (c) & (b) & (a) \\
\hline
\end{tabular}

3.4 Agronomic efficiency

Agronomic efficiency (AE) is calculated in units of yield increase per treatments of NP fertilizer applied. It more closely reflects the direct production impact of an applied inorganic fertilizer. The result showed that there was a significant effect of biofertilizers and FSA application and also application of inorganic fertilizers on yield of maize.

Biofertilizers application with 40\% NP fertilizers increased grain yield of maize up to $5.28 \mathrm{Kg} \mathrm{Kg}^{-1}$. Furthermore, increasing the dosage of NP fertilizer to $80 \%$, the application of biofertilizers decreased the yield to $0.86 \mathrm{Kg} \mathrm{Kg}^{-1}$ (Table 5). Application of FSA with $40 \% \mathrm{NP}$ fertilizers increased grain yield up to $6.22 \mathrm{Kg} \mathrm{Kg}^{-1}$. However, the combination of biofertilizers and FSA applications with $100 \%, 80 \%$ and $60 \% \mathrm{NP}$ fertilizer increased grain yield of maize by $5.40,4.20,2.16 \mathrm{Kg} \mathrm{Kg}$ 1 , respectively.

Table 5. Agronomic efficiency of NP fertilizers application on maize

\begin{tabular}{lll}
\hline Treatment & $\begin{array}{l}\text { Grain yield } \\
\text { of maize } \\
\left(\mathrm{Kg} \mathrm{ha}^{-1}\right)\end{array}$ & $\begin{array}{l}\text { Agronomic } \\
\text { efficiency }(\mathrm{Kg} \\
\left.\mathrm{Kg}^{-1}\right)\end{array}$ \\
\hline Control (100\% NP fertilizer) & 2844 & - \\
$80 \%$ NP fertilizer & 2660 & 1.32 \\
$60 \%$ NP fertilizer & 2456 & 3.71 \\
$40 \%$ NP fertilizer & 2237 & 8.72 \\
$\begin{array}{l}\text { Biofertilizers + 100\% NP } \\
\text { fertilizer }\end{array}$ & 3447 & 3.46 \\
$\begin{array}{l}\text { Biofertilizers + 80\% NP fertilizer } \\
\text { Biofertilizers + 60\% NP fertilizer }\end{array}$ & 2965 & 0.86 \\
$\begin{array}{l}\text { Biofertilizers + 40\% NP fertilizer } \\
\text { FSA + 100\% NP fertilizer }\end{array}$ & 2476 & 1.64 \\
FSA + 80\% NP fertilizer & 3044 & 1.14 \\
FSA + 60\% NP fertilizer & 2860 & 0.11 \\
FSA + 40\% NP fertilizer & 2545 & 2.86 \\
$\begin{array}{l}\text { Biofertilizers and FSA + 100\% } \\
\text { NP fertilizer }\end{array}$ & 3785 & 6.22 \\
$\begin{array}{l}\text { Biofertilizers and FSA + 80\% NP } \\
\text { fertilizer }\end{array}$ & 3430 & 4.40 \\
$\begin{array}{l}\text { Biofertilizers and FSA + 60\% NP } \\
\text { fertilizer }\end{array}$ & 3070 & 2.16 \\
$\begin{array}{l}\text { Biofertilizers and FSA + 40\% NP } \\
\text { fertilizer }\end{array}$ & 2715 & 1.85 \\
\hline & & \\
\hline
\end{tabular}




\section{Discussion}

In general, the treatment of biofertilizers and FSA can significantly increase soil organic carbon, chlorophyll content, and PSB population. This shows that the biofertilizers will have an optimal effect if there is an energy source for growth obtained from FSA. This proves that biofertilizers is more effective to promote plant growth when combined with FSA. Application of biofertilizers combined with FSA increases the soil organic carbon. The soil amendment used consists of materials which are rich in organic carbon such as compost with raw materials of bagasse, biochar, dolomite, hemic acid and guano which can increase the organic carbon content in the soil.

The application of biofertilizers can also help increase organic carbon by the decomposition process carried out by bacteria. Therefore, soil amendment and biofertilizers can increase the organic carbon content higher than other treatments. Compost and biochar are the source of carbon and energy for microbes in biological fertilizer. In this atudy, the compost has a $\mathrm{C} / \mathrm{N}$ ratio of 23 . This is supported by the results of research by Husna et al. (2019) showing the highest viability of phosphate solubilizing microorganisms in biochar carriers.

Increasing soil organic carbon greatly affects soil health (Tully and McAskill, 2020). The organic carbon can affect soil structure, aeration, and water holding capacity (Colombi et al., 2019). These soil properties can support plants to produce in the soil. Provision of soil amendment and biofertilizers can increase organic carbon in the soil. Provision of soil amendment and $\mathrm{P}$ solubilizing microbes and $\mathrm{N}$ fixers can increase organic carbon by up to $75 \%$ in the soil after three years of application (Debska et al., 2016). The application of soil amendment and biofertilizers can increase organic carbon and affect other chemical properties that can support soil health.

The advantages of biofertilizers include reducing the use of chemical fertilizers and environmental pollution, increasing the availability of nutrients and enhancing plant growth, and improve the physical, chemical and biological properties of the soil (Wahane et al., 2020). Yasmin et al. (2020) reported that beneficial microbes application increased yield and available nutrient $(\mathrm{N}, \mathrm{P}, \mathrm{K})$ and reduced the nitrogen fertilizer rate. Furthermore, Albdaiwi et al. (2019) stated that some microbes as Plant GrowthPromoting Rhizobacteria (PGPR) increase nutrient availability, yield of crops and substitute to chemical fertilizers. The formulated soil amendment is a source of energy for soil macro and microbes. Addition of soil amendment will increase microbiological activities and populations, especially those related to the decomposition and mineralization of organic matter (Stevenson, 1986).

Application of biofertilizers resulted in considerable increase in the chlorophyll content of maize plant leaf tissue. In this study, biofertilizers which contain phosphate solubilizing bacteria and $\mathrm{N}$-fixing bacteria improved the growth of maize and increased chlorophyll content of maize plant leaf tissue. Khan (2018) observed chlorophyll content increases with biofertilizers application. The application of biofertilizers has been reported to improve the soil health and escalate the efficiency of applied fertilizers (Simarmata et al.. 2017).
Chlorophyll content is one of the parameters for plants to grow well. Chlorophyll is a green pigment in plants playing a role in the photosynthesis process of plants (Li et al., 2018). Chlorophyll is formed from several nutrients, so if the plant does not get the optimum nutrient, the chlorophyll content in the plant is not optimal. Table 2 shows that the application of biofertilizers and ameliorants combined with $100 \%$ of the recommended dosage of inorganic fertilizers can increase the chlorophyll content higher than other treatments. This could be due to the $100 \%$ dose of inorganic fertilizer affecting the chlorophyll content of leaves. The availability of nutrients in the soil, especially the essential nutrients $\mathrm{N}, \mathrm{P}$ and $\mathrm{K}$ can increase chlorophyll content in plants (Eisvand et al., 2018).

The higher the supply of nitrogen into plants, the higher the chlorophyll content of plants in the leaves so that the photosynthesis process is faster (Bassi et al., 2018). The $\mathrm{N}$ element received by plants is obtained from the application of inorganic fertilizers which are not reduced from the recommended dosage and the use of $\mathrm{N}$-fixing bacteria.

Table 4 shows that biofertilizers and FSA combined with inorganic fertilizers $100 \%$ of the recommended dosage resulting in the highest of PSB population compared to other treatments. The biofertilizers in this study contained PSB (Bulkhoderia vietnamiensi and Enterobacter ludwigii). The increase of PSB population was accompanied by soil amendment applied to the soil which can be a source of energy for bacteria to reproduce. The provision of ameliorants also increased PSB population because it helped bacteria grow and get a source of energy.

The increase in the population of $\mathrm{N}$-fixing bacteria was caused by the application of biofertilizers and soil amendment. The biofertilizers used in this study contained $\mathrm{N}$-fixing microorganisms, namely Azotobacter chroococcum and Azospirillum sp. However, increasing the $\mathrm{N}, \mathrm{P}$ fertilizer will inhibited the $\mathrm{N}$-fixing bacteria. Increasing population of $\mathrm{N}$-fixing bacteria improves soil health and increases plant productivity (Tahat et al., 2020).

Based on the measurement of agronomic efficiency, the application of biofertilizers and FSA with $60-100 \%$ NP fertilizer could increase maize yields. $100 \%$ of the $\mathrm{N}, \mathrm{P}$ fertilizer will inhibit the $\mathrm{N}$-fixation bacteria. In addition, the combination of biofertilizers and FSA application increased fertilizers efficiency by $40 \%$. This is in line with research by Cisse et al. (2019) that application of $20 \mathrm{~kg} \mathrm{ha}^{-}$ 1 biofertilizer reduced at least $50 \%$ of the NPK fertilization.

\section{Conclusion}

Application of biofertilizers (N-fixer bacteria Azotobacter chroococcum, and Azospirillum sp. and phosphate solubilizing bacteria Bulkholderia vietnamiensi and Enterobacter ludwigii) and formulated soil amendment (mixture of compost 50\%, biochar 20\%, humid acid $1 \%$, and guano 9\%) can significantly increase soil organic carbon, chlorophyll content, PSB population and yield of maize. The highest population of PSB and Nfixing bacteria, chlorophyll leaves and yield of maize were obtained by application of $1.200 \mathrm{~g} \mathrm{ha}^{-1}$ of biofertilizers and $2 \mathrm{t} \mathrm{ha}^{-1}$ of formulated soil amendment. Additionally, fertilizers efficiency was increased by $40 \%$. 


\section{Acknowledgment}

We are grateful to staff Laboratory of Soil Biology Faculty of Agriculture, Universitas Padjadjaran and staff Horticultural Seed Development Center and Various Plants Pasir Banteng, Sumedang-West Java for their supporting and valuable advice of this work.

\section{Funding}

This research was funded by Academic Leadership Grant (ALG) Universitas Padjadjaran.

\section{References}

Albdaiwi RN, Khyami-Horani H and Ayad JY. 2019. Plant growth-promoting rhizobacteria: an emerging method for the enhancement of wheat tolerance against salinity stress-(Review). Jordan J Biol Sci., 12 (5): 525 - 534.

Bassi D, Menossi M and Mattiello L. 2018. Nitrogen supply influences photosynthesis establishment along the sugarcane leaf. Sci Rep., 8(1) :1-13.

Chen Q and Liu S. 2019. Identification and characterization of the phosphate-solubilizing bacterium Pantoea sp. S32 in reclamation soil in Shanxi, China. Front Microbiol., (10) Article 2171.

Cisse A, Arshad A, Wang X, Yattara F, and Hu Y. 2019. Contrasting impacts of long-term application of biofertilizers and organic manure on grain yield of winter wheat in north china plain. Agronomy., 9(6): 312.

Colombi T, Walder F, Büchi L, Sommer M, Liu K, Six J, van der Heijden MGA, Charles R and Keller T. 2019. On-farm study reveals positive relationship between gas transport capacity and organic carbon content in arable soil. SOIL, 5: 91-105,

Debska B, Dlugozs J and Piotrowska-Dlugozs A. 2016. The impact of a bio-fertilizer on the soil organic matter status and carbon sequestration-results from a field-scale study. J Soil Sediments., 16 (10): 2335-2343.

Eisvand HR, Kamael H, and Nazarian F. 2018. Chlorophyll fluorescence, yield components of bread wheat affected by phosphate bio-fertilizer, zinc and boron under late-season heat stress. Photosynthetica., 56 (4): 1287-1296.

Fitriatin BN, Silpanus R, Sofyan ET, Yuniarti A, and Turmuktini T. 2019. Effect of microbial fertilizers and dosage of NPK on growth and yield of upland rice (Oryza sativa L.). Int. j. environ. agric. Biotech., 4 (4): 899-902.

Fitriatin BN, Fauziah D, Fitriani FN, Ningtyas DN, Suryatmana P, Hindersah R, Setiawati MR and Simarmata T. 2020. Biochemical activity and bioassay on maize seedling of selected indigenous phosphate-solubilizing bacteria isolated from the acid soil ecosystem. Open Agric., 5: 300-304.

Gentili F and Jumpponen A. 2006. Potential and possible uses of bacterial and fungal Biofertilizers. In: Handbook of Microbial Biofertilizers. Haworth Press, Technology \& Enginering, New York, pp 1-28.

Husna N, Budianta D, Munandar, and Napoleon A. 2019. Evaluation of several biochar types as inoculant carrier for indigenous phosphate solubilizing microorganism from acid sulphate soil. J Ecol. Eng., 20 (6): 1-8.

Itelima JU, Bang WJ, Sila MD, Onyimba IA, and Egbere OJ. 2018. Bio- fertilizers as key player in enhancing soil fertility and crop productivity: A review. Direct Res. J. Agric. and Food Sci., 6 (3) :73-83
Jayakumara N, Paulraja P, Sajeesha P, Sajnaa K, and Zinneera A. 2019. Application of native phosphate solubilizing bacteria for the use of cheap organic and inorganic phosphate source in agricultura practise of Capsicum annum (Chili) - A pilot scale field study. Mater. Today: Proc., 16 :1630-1639. Available online at www.sciencedirect.com

Khan HI. 2018. Appraisal of biofertilizers in rice: to supplement inorganic chemical fertilizer. Rice Sci., 25(6): 357-362. Available online at www.sciencedirect.com

Li Y, He N, Hou J, Xu L, Liu C, Zhang J, Wang Q, Zhang X, and Wu X. 2018. Factors influencing leaf chlorophyll content in natural forests at the Biome scale. Front. Ecol. Evol., 6: article 64.

Macik M, Gryta A, and Frąc M. 2020. Biofertilizers in Agriculture: An overview on concepts, strategies and effect on soil microorganisms. Adv. Agron., 162: 31-87.

Nelson D W, Sommers L E. 1982. Total carbon, organic carbon, and organic matter. In: Page A L, Miller R H, Keeney D R, eds., Methods of Soil Analysis. Part 2. Chemical and Microbiolobical Properties. Soil Science Society of America, American Society of Agronomy, Madison, WI. USA. pp. 539-594.

Simarmata T, Hersanti, Turmuktini T, Fitriatin, BN, Setiawati MR and Purwanto. 2017. Application of bioameliorant and biofertilizers to increase the soil health and rice productivity. HAYATI J. Biosci., 23 (4): 181-184.

Steenhoudt O. and Vanderleyden J. 2000. Azospirillum, a freeliving nitrogen-fixing bacterium closely associated with grasses: genetic, biochemical and ecological aspects. FEMS Microbiol. Rev., 24: 487-506.

Stevenson FJ. 1986. Cycles of Soil Carbon, Nitrogen, Phosphorus, Sulfur, Micronutrient. A Wiley-Inetrscience Publication John Wiley \& Sons.

Tahat, MM, Alananbeh KM, Othman YA, and Leskovar DI. 2020. Soil health and sustainable agriculture. Sustainability., 12(12): 4859.

Tully KL and McAskill C. 2020. Promoting soil health in organically managed systems: a review. Org. Agric., 10(3): 339358.

Wahane MR, Meshram NA, More SS and Khobragade NH. 2020. Biofertilizer and their role in sustainable agriculture-A review. $J$. Pharm. Innov., 9(7): 127-130.

Wu F, Li J, Chen Y, Zhang L, Zhang Y, Wang S, Shi X, Li L and Liang J. 2019. Effects of phosphate solubilizing bacteria on the growth, photosynthesis, and nutrient uptake of Camellia oleifera Abel. Forests., 10 (4) : 348-357

Yasmin F, Othman R and Maziz MNH. 2020. Yield and nutrient content of sweet potato in response of Plant Growth-Promoting Rhizobacteria (PGPR) inoculation and $\mathrm{N}$ fertilization. Jordan $J$ Biol Sci., 13 (1) : 117-122.

Zemichael B, Dechassa, N and AbayF. 2017. Yield and nutrient use efficiency of bread wheat (Triticum aestivum L.) as influenced by time and rate of nitrogen application in Enderta, Tigray, Northern Ethiopia. Open Agric., 2(1): 611-624.

Zhang J, Liu J Y, Meng L Y, Ma Z Y, Tang X Y, Cao Y Y and Sun L .2012. Isolation and characterization of plant growthpromoting rhizobacteria from wheat roots by wheat germ agglutinin labeled with fluorescein isothiocyanate. J. Microbiol., 50 (2): 191-198. 